Cell Research (2001); 11(3):231-236

http://www.cell-research.com

\title{
Differential mercury volatilization by tobacco organs expressing a modified bacterial merA gene
}

\author{
He Yu Keำ ${ }^{1,2}$, Jian Ge Sun1, Xian Zhong FenG ${ }^{1,2}$, Mihaly Czakó ${ }^{1}$, LÁSZLó MÁRTON ${ }^{1}$
}

${ }^{1}$ Department of Biological Sciences, University of South Carolina, 700 Sumter Street, Columbia, SC29208, USA

${ }^{2}$ National Laboratory of Plant Molecular Genetics, Shanghai Institute of Plant Physiology and Ecology, Chinese Academy of Sciences, 300 Fenglin Road, Shanghai 200032, China

Communicated by Lá szló Má rton, Department of Biological Sciences, University of South Carolina, 700 Sumter Street, Columbia, SC29208, USA

\begin{abstract}
Mercury pollution is a major environmental problem accompanying industrial activities. Most of the mercury released ends up and retained in the soil as complexes of the toxic ionic mercury $\left(\mathrm{Hg}^{2+}\right)$, which then can be converted by microbes into the even more toxic methylmercury which tends to bioaccumulate. Mercury detoxification of the soil can also occur by microbes converting the ionic mercury into the least toxic metallic mercury $\left(\mathrm{Hg}_{0}\right)$ form, which then evaporates. The remediation potential of transgenic plants carrying the MerA gene from E. coli encoding mercuric ion reductase could be evaluated.A modified version of the gene, optimized for plant codon preferences (merApe9, Rugh et al. 1996), was introduced into tobacco by Agrobacterium-mediated leaf disk transformation. Transgenic seeds were resistant to $\mathrm{HgCl}_{2}$ at $50 \mu \mathrm{M}$, and some of them (10-20\% ) could germinate on media containing as much as $350 \mu \mathrm{M} \mathrm{HgCl}_{2}$, while the control plants were fully inhibited or died on $50 \mu \mathrm{M} \mathrm{HgCl}_{2}$. The rate of elemental mercury evolution from $\mathrm{Hg}^{2+}$ (added as $\mathrm{HgCl}_{2}$ ) was 5-8 times higher for transgenic plants than the control. Mercury volatilization by isolated organs standardized for fresh weight was higher (up to 5 times) in the roots than in shoots or the leaves. The data suggest that it is the root system of the transgenic plants that volatilizes most of the reduced mercury $\left(\mathrm{Hg}_{0}\right)$. It also suggests that much of the mercury need not enter the vascular system to be transported to the leaves for volatilization. Transgenic plants with the merApe9 gene may be used to mercury detoxification for environmental improvement in mercury-contaminated regions more efficiently than it had been predicted based on data on volatilization of whole plants via the upper parts only (Rugh et al. 1996).
\end{abstract}

Key words: Environment, heavy metals, mercury, remediation, tobacco.

\section{INTRODUCTION}

Environmental pollution is an increasing problem both for developing and developed countries. Mercury, both in organic and ionic form, is one of the most hazardous pollutants among the heavy metals[1]and its accumulation in human body re-

* Corresponding authors: L Má rton: Fax: 001-803-7774002;

E-mail: marton@biol.sc.edu; He YK: Fax:0086-21-64042385; E-mail: heyk@iris.sipp.ac.cn

Received July-17-2001 Revised Aug-24-2001 Accepted Aug-252001 sults in inactivation of metabolic enzymes and structural proteins[2], [3] giving rise to serious health problems (Minamata-syndrome).

Usually, mercury pollution is caused by industrial and agricultural activities, releasing mercury into air, water and land. Mercury is used in gold mining and huge amounts of mercury wastes produced in some chemical factories and fossil fuel burning. Farmers still use cheap mercury-based fungicides in certain regions. In some industrial- 
ized areas mercury in river water and soil has reached dangerous levels. The primary ionic mercury pollution is secondarily converted into organomercurials on site. Organomercurial compounds are 1-2 orders of magnitude more toxic to some eukaryotes and are more likely to biomagnify across trophic levels than ionic mercury $\left[\mathrm{Hg}^{2+}\right][1]$, [4].

There are Gram-negative bacteria with mercury-resistance that is conferred on by a mercuric reductase encoded by the merA gene[5]. merA efficiently catalyzes the reduction of $\mathrm{Hg}^{2+}$ to elemental mercury $\left(\mathrm{Hg}_{0}\right)$ which is then evaporated from the cell. The original merA gene was used to transform the model plant species Arabidopsis thaliana with the intention to develop mercury-resistant/volatilizing plants, but the transformants failed to express the mRNA and the protein[6]. When the merA gene was mutagenized in order to modify codons to those preferred by plants, the resultant merApe 9 gene was efficiently expressed. MerA9pe gene enabled Arabidopsis plants to grow on toxic levels of $\mathrm{Hg}^{2+}$ by converting the more toxic ionic mercury to elemental mercury[6], proving that an efficient new tool was created for phytoremediation technologies. Plants carrying this modified merA gene can extract, sequester, and detoxify mercury pollutants [7]. The mercury volatilization trait was also introduced into yellow poplar and tobacco[7], [8]. Mercury volatilizing transgenic plants could be incorporated into new environmental remediation technologies providing a more environmental friendly, cost effective and sustainable alternative compared to chemical and physical recovery of mercury from the polluted wastes[9].

Tobacco (Nicotiana tabacum) is an important cash crop. Converting tobacco to a mercury volatilizing plant could create a multiple use crop that can be grown in mercury-contaminated soil[7]. Since tobacco is much larger than Arabidopsis, and has extensive root systems capable of extracting mercury, its potential for mercury evaporation is greater. Elemental mercury evolution via the upper parts of tobacco has been reported[7]. In this report, we describe the differential elemental mercury evolution capacities of roots, leaves and stems of tobacco transgenic for the merApe9 gene.

\section{MATERIALS AND METHODS}

\section{Construction of transgenic plants}

The plasmid pVSTImerApe9[6] in Agrobacterium strain LBA4404 were kindly provided by Prof. R. B. Meagher (Dept. of Genetics, Univ. of Georgia, Athens). In this binary vector, the coding sequence of merApe9 is under the control of the cauliflower mosaic virus $35 \mathrm{~S}$ RNA promoter, and there is also a kanamycin resistance gene in the T-region.

Leaf sections of tobacco cv. Xanthii were cocultivated[10] with the Agrobacterium and kanamycin-resistant shoots selected on a medium based on Murashige and Skoog salts (Sigma) containing $3 \mathrm{mg} / \mathrm{L} \mathrm{N6}$-benzyladenine and $50 \mathrm{mg} / \mathrm{L}$ kanamycin monosulfate (ICN Biomedicals, Aurora, $\mathrm{OH}$ ). The primary transformant (T0) shoots were transplanted, allowed to flower and then selfed. The seeds were harvested 90 days later. The seeds from the selfed transformants were selected for resistance to kanamycin [10], and the surviving plantlets (T1) were transferred to soil and grown in greenhouse.

\section{Germination and growth experiments}

Seeds from the individual T0 plants transgenic for merApe9 gene were harvested and used for germination experiments. Wild-type seeds were used as negative control. Seeds were surface sterilized, and germinated on $1 \%(\mathrm{w} / \mathrm{v})$ phytagar plates (GIBCO/BRL) made with Murashige and Skoog salts ( $4.3 \mathrm{~g} / \mathrm{L}$, Sigma) containing $\mathrm{HgCl}_{2}$ at various concentrations. $\mathrm{HgCl}_{2}$ was added to the autoclaved medium before solidification. Seedlings were grown at $25{ }^{\circ} \mathrm{C}$ under a 16 -h light/8-h dark regime. Thirty days after sowing, the seedlings were transplanted in soil and kept in the greenhouse.

\section{Southern and Northern blotting}

A 1.7-kb diagnostic DNA fragment spanning the complete coding sequence of merApe9 was generated using the 5' primer 5' - GGA TCC AAT GAG CAC TCT CAA AAT CAC-3' and the 3' primer 5' -GCC TCA CCC GGC GCA GCA GGA-3' ). Transformants were verified by Southern blotting as described in[11]. Total DNA was digested with EcoRI, the fragments were resolved by electrophoresis on a $0.8 \%$ agarose gel, and blotted to nylon membrane. The 1.7-kb DNA was labeled with $\left[{ }^{32} \mathrm{P}\right]$ dCTP by using the random priming method[12] 
Hybridization conditions and autoradiography were carried out as described[13]. The 1.7-kb merApe9 DNA fragment was used for hybridization.

\section{Mercury vapor assay}

A Jerome 431 mercury vapor analyzer (Arizona Instruments, Phoenix, AZ) was used to measure the volatilized mercury released from the plant tissues[7]. Seedlings resistant to both kanamycin (50 $\mu)$ and $\mathrm{HgCl} 2(50 \mu \mathrm{M}$ and higher) were selected from double-selective plates 15 days after sowing and transferred in soil for growth in greenhouse. Both 20-day old seedlings and 70-day old greenhouse plants were used for mercury vapor assay respectively. Each seedling sample consisted of 4060 seedlings of the same sib of the transgenic line. The 55-day old plants were rinsed free of soil, dissected and separated into root, shoot, and stem fractions. The plant samples $(0.2-2.0 \mathrm{~g})$ were incubated in $100 \mathrm{ml}$ or $200 \mathrm{ml}$ of assay medium[6] containing $25 \mu \mathrm{M} \mathrm{HgCl}_{2}$ in 2000 -ml flask with a side arm for gas control. The seedlings or plant organs were immersed in $\mathrm{HgCl}_{2}$ solution and the mercury vapor evolved was sampled by sparge-evacuation of the headspace over the course of a ten-minute assay. Each sample was assayed with fresh $\mathrm{HgCl}_{2}$ solution.

\section{RESULTS}

Mercury resistance of transgenic tobacco seedlings

A plant codon-optimized version of the mercury reductase gene, merApe9[6] was introduced into tobacco by Agrobacterium-mediated leaf disk transformation. In the pVSTImerApe 9 binary vector, the coding sequence of merApe9 is under the control of the cauliflower mosaic virus 35S RNA promoter, and there is also a kanamycin resistance gene in the T-region.

Primary transformants $\left(\mathrm{T}_{0}\right)$ were picked from kanamycin-containing selective plates and their resistance to kanamycin was confirmed by the ability to root in fresh kanamycin medium. These T0 shoots were transplanted to potting soil where they were allowed to flower and then selfed. The seeds from the selfed transformants were selected for resistance to kanamycin[10], and the resistant plantlets (T1) transferred to soil and grown in the greenhouse.

$\mathrm{T}_{1}$ seeds were also screened for $\mathrm{Hg}^{2+}(50-350 \mu$ $\mathrm{M}$ range) resistance ( $\mathrm{Tab} 1$ ). $\mathrm{T}_{1}$ seeds showed segregation characteristic for a single expressed transgene locus on the minimally selective $50 \mu \mathrm{M}$ mercury medium. Germination of the control seeds was inhibited by mercuric chloride of this concentration. Germination percentage became significantly lower when the $\mathrm{HgCl}_{2}$ concentration increased, indicating a different level of resistance of homozygous and heterozygous seedlings. At 150 $\mu \mathrm{M}$, apparently only the homozygotes survived demonstrating the effect of gene dosage on mercury resistance. A rare seedling (e.g. 1 out of 40) was resistant to as much as $350 \mu \mathrm{M} \mathrm{HgCl}_{2}$, indicating differences in gene expression within the sib population.

Most seedlings of the MerA9-2 and MerA-3 lines grew vigorously in the presence of $50 \mu \mathrm{M} \mathrm{HgCl}_{2}$ producing strong shoots and green leaves, even though some of them died within 2-3 weeks. The most resistant plants from each selfed sib were then transplanted to soil and cultivated in the greenhouse. In greenhouse, growth of mercury-resistant seedlings was slightly slower than that of the control seedlings in the first week after transplanting. However, these plants were the same size as control plants 30 days later. They started flowering and setting seeds after 9 weeks.

The transgenic nature of individual plants was also verified by Southern hybridization. Transgenic line MerA-3 (Fig 1) shows a strong hybridization signal when a PCR fragment of the merApe9 gene

Tab 1. Mercury resistance of transgenic seedlings. The seedlings with green true leaves were scored as germinated seeds.

\begin{tabular}{cccc}
\hline \multicolumn{4}{c}{ Germination rate $(\%)$} \\
$\mathrm{HgCl}_{2}(\mu \mathrm{M})$ & Control & MerA-2 & MerA-3 \\
\hline 0 & 88 & 80 & 83 \\
50 & 0 & 56 & 62 \\
100 & 0 & 28 & 62 \\
150 & 0 & 23 & 6 \\
200 & 0 & 3 & 3 \\
250 & 0 & 0 & 3 \\
300 & 0 & 5 & 8 \\
350 & 0 & 0 & 3 \\
\hline
\end{tabular}


was used as probe. By contrast, no hybridization signal was seen with DNA from a wild-type plant.

The copy number of the transgene could be in-

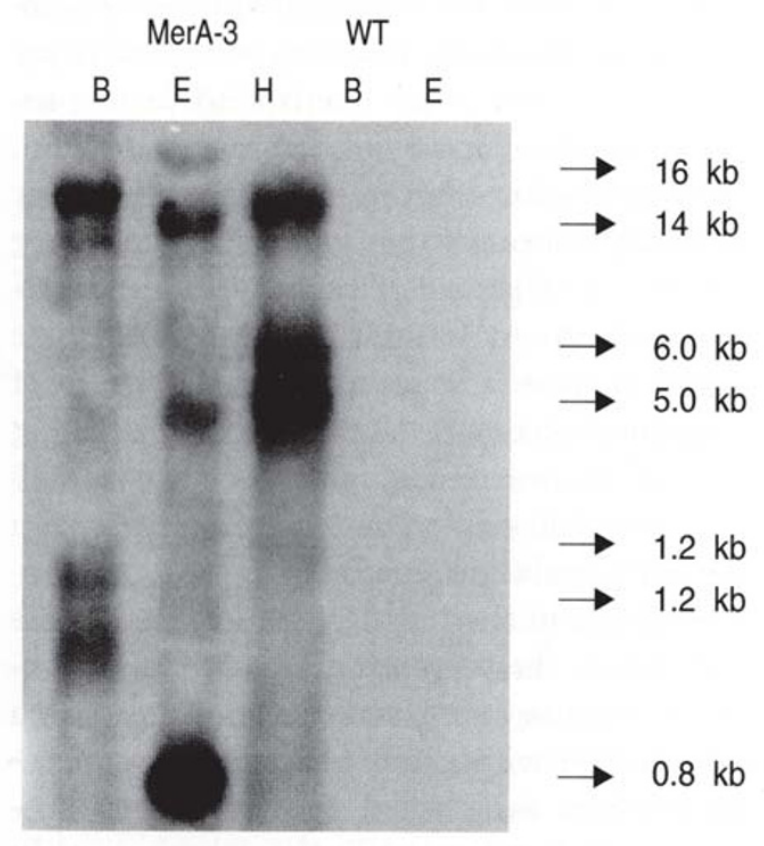

Fig 1. Southern hybridization of transgenic plant lines of tobacco. Total DNA of transgenic lines and wild type was digested respectively with BamHI, EcoRI and HindIII hybridized with $\alpha{ }^{32}$ P-labeled BamHI- XhoI merApe9 fragment. MerA-3, one of merApe9 transgenic lines, was shown to have strong signal of transcriptional expression.

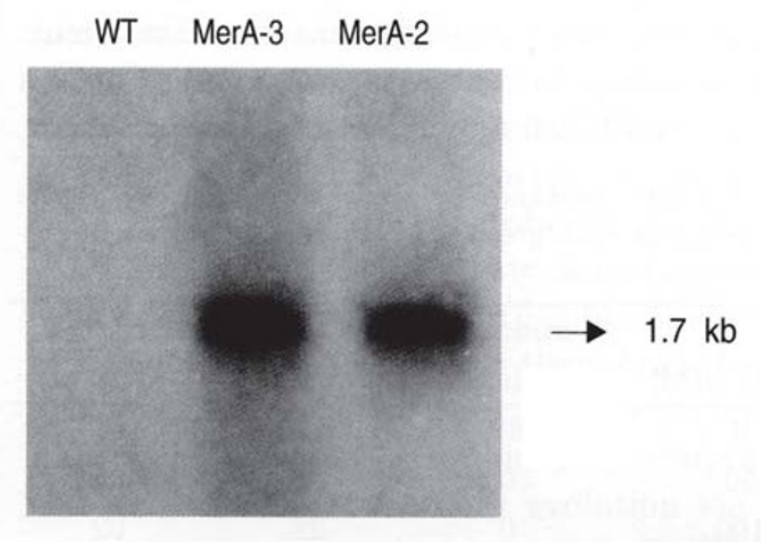

Fig 2. Northern hybridization of transgenic plant lines of tobacco. Total RNA of lines was hybridized with $\alpha{ }^{32} \mathrm{P}$-labeled BamHI- XhoI merApe9 fragment. MerA-3 and MerA-2, two of transgenic lines, was shown to have strong signal of transcriptional expression while wild type (WT) of tobacco were indicated without signal of expression. ferred from hybridization pattern. There is an EcoRI site within the merApe9 gene. Two EcoRI, and one

each of BamHI and HindIII (neither one occurring within the gene) would be expected for a transgenic plant with a single copy of the transgene. The strongest hybridization bands clearly indicate single copy integration of merApe9 in the MerA-3 line (the weaker bands are from partial digestion by and star activity of the enzymes).

Steady-state mRNA levels did not differ between the transgenic lines analyzed. Northern blots showed a strong 1.7-kb RNA band in the MerA-3 and MerA2 lines but not in wild-type (Fig 2). This is the size predicted for the MerApe9 mRNA.

\section{Mercury volatilization}

Kanamycin-resistant seedlings from the selfed sibs of each transgenic line were cultured on selective, kanamycin-containing medium for 20 days, then the leaves, stems and roots were separated. The rate of mercuric ion reduction was measured in the different organs of each transgenic sib with a mercury vapor analyzer. As it can be seen in Fig 3 , much more elemental mercury evolved from the tissues of MerA-3 plants those of the control. Apparently, the roots produced the most mercury vapor, followed by leaves and stems in either MerA-3 line or in the control. The rate of elemental mercury evolution from $\mathrm{Hg}^{2+}$ (added as $\mathrm{HgCl}_{2}$ ) was much higher for transgenic plants than the control. Mercury volatilization was assayed again at a later stage, using 70day old greenhouse-grown plants. Since the plants were too big to assay as a whole, leaves, stems and roots were harvested and $5 \mathrm{~g}$ fresh weight of tissue was suspended in $200 \mathrm{ml}$ assay buffer as above. The increased mercury evolution of MerA-3 plants was far more obvious in this experimental setup (Fig 4) than before with the seedlings (Fig 3). Again the most mercury vapor was released by the root tissue (238 $\mu \mathrm{g} / \mathrm{g}$ fresh weight), followed by the leaf $(69 \mu$ $\mathrm{g} / \mathrm{g})$ and the stem $(41 \mu \mathrm{g} / \mathrm{g})$. The figures are approximately nine-, eight- and five-times higher than the respective figures for the control plant, respectively. On the contrary, MerA-2 plant failed to show increased mercury evolution; the amount of elementary mercury evolved from different organs of MerA2 plants was nearly the same as that of control except that the stem showed higher rate of elementary mercury evolution. 
Interestingly, the mercury evolution capacity of individual transgenic plants may differ greatly. Both MerA-3 and MerA-2 was highly resistant to mercuric chloride and showed approximately equal steadystate mRNA levels while only MerA-3 showed significant mercury volatilization. A potential explanation can be later stage silencing of the transgene

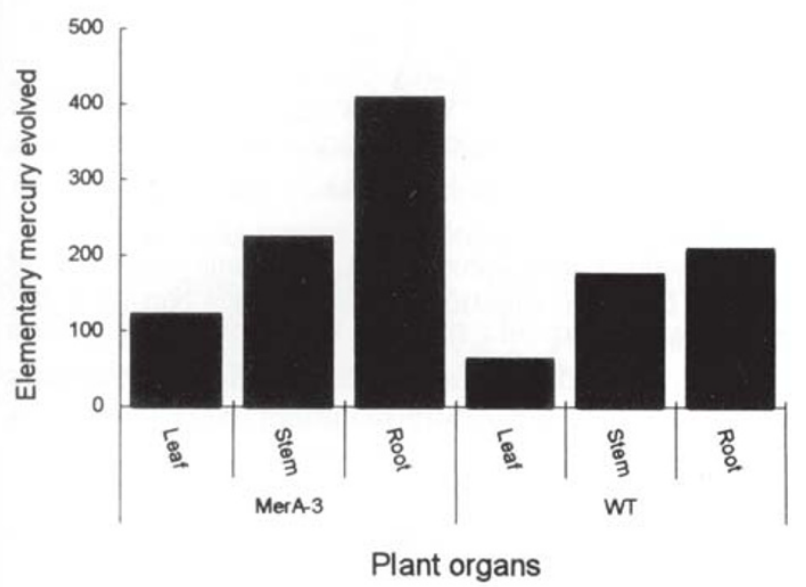

Fig 3. Amount of $\mathrm{Hg}^{0}$ released from 20-d old transgenic tobacco seedlings from kanamycin-containing medium. Leaves, roots and stems without leaf were cut from seedlings of transgenic line MerA9-3 and WT (wild-type) and dipped in $\mathrm{HgCl} 2$ solution for evolution of $\mathrm{Hg}^{0}$. Amount of $\mathrm{Hg}^{0}$ evolved was indicated with microgram of $\mathrm{Hg}^{0}$ per gram of fresh plant tissue $(\mu \mathrm{g} / \mathrm{g})$.

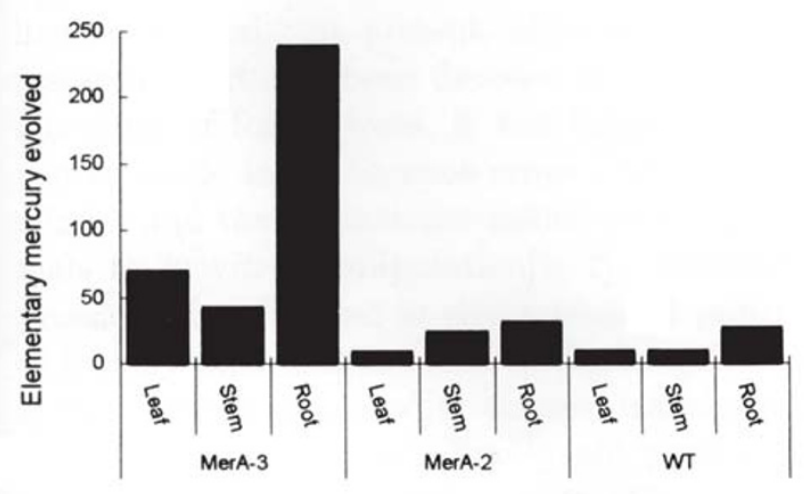

Plant organs

Fig 4. Amount of $\mathrm{Hg}^{0}$ released from transgenic tobacco plants of 70 day old. Leaves, roots and stems without leaf were cut from seedlings of transgenic lines and WT (wild type) grown in greenhouse containing $50 \mathrm{mg} / \mathrm{L}$ kanamycin, and dipped in $\mathrm{HgCl}_{2}$ solution for evolution of $\mathrm{Hg}^{0}$. Amount of $\mathrm{Hg}^{0}$ evolved was indicated with microgram of $\mathrm{Hg}^{0}$ per gram of fresh plant tissue $(\mu \mathrm{g} / \mathrm{g})$. expression at the protein level.

\section{DISCUSSION}

Plants are capable of transforming mercury. Kozuchowski and Johnson reported that plants absorb mercury through the roots and then volatilize it from leaves as $\mathrm{Hg}(0)$ [14]. Our present data suggest that it is the root system of the transgenic plants that volatilizes most of the reduced mercury $\left(\mathrm{Hg}^{0}\right)$. It also suggests that much of the mercury need not enter the vascular system from where it would be transported to the leaves for volatilization. Transgenic plants with the merApe9 gene may be used to mercury detoxification for environmental improvement in mercury-contaminated regions more efficiently than it had been predicted. Previous data were obtained in a setup where the roots were excluded from the measurements and volatilization via the leaves only were measured[6]. Actually a large proportion of mercury is volatilized directly by the roots. Since tobacco is a fast growing crop with large fresh mass, transgenic lines resistant to mercury could be used to remediate mercury-contaminated region with simple agrotechnology. The organomercurial lyase ( MerBpe) gene has also been introduced into tobacco [15]. The gene product converts the dangerous methylmercury and other organic mercury derivatives to ionic mercury which can then be reduced to $\mathrm{Hg}^{0}$ by MerA[15]. Transgenic plants carrying the individual mercury metabolic genes can be crossed to create a universal mercury removing plant for areas where methylmercury and ionic mercury pollution is simultaneously present[16], [15], [9]. Tobacco is especially attractive for this purpose because of the ease of hybridization.

Furthermore, mercury volatilization trait in the root tissue is important for understanding the mechanism of plant response to ionic mercury. A strong root system could be used as a bioreactor for phytoremediation as it used for molecular farming [17]. A mobile ionic mercuric pollution could be reduced by draining through a strong root system of hyroponically grown tobacco or other merA transgenic plants. Yellow poplar ( Liriodendron tulipifera) is the first woody plant reported to express modified mercuric reductase gene constructs [8]. 


\section{REFERENCES}

[1] Hassett-Sipple B, Swartout J, Schoeny R, Mahaffey KR, Rice GE. Mercury Study Report to Congress: Volume V: Health Effects of Mercury and Mercury Compounds. EPA452/R-97-007. 1997, USA Environmental Protection Agency: Washington, DC. 5:1-349.

[2] Harada M. Minamata Disease - Methylmercury Poisoning in Japan Caused by Environmental-Pollution. Crit Rev Toxicol 1995; 25:1-24.

[3] Rahola T, Hattula T, Korolainen A, Miettinen JK. Elimination of free and protein-bound ionic mercury in man. Ann Clin Res 1973; 5:214-9.

[4] Tsuzuki T, Irukayama K. Minamata disease. 1977, Amsterdam: Elsevier.

[5] Summers AO, Biotransformation of Mercury Compounds, in Reducing Risks from Environmental Chemicals through Biotechnology, G Omenn, Editor. 1988, Plenum Press: New York.

[6] Rugh CL, Wilde HD, Stack NM, Thompson DM, Summers AO, Meagher RB. Mercuric ion reduction and resistance in transgenic Arabidopsis thaliana plants expressing a modified bacterial merA gene. Proc Natl Acad Sci USA 1996; 93:3182-7.

[7] Heaton ACP, Rugh CL, Wang NJ, Meagher RB. Phytoremediation of mercury- and methylmercury- polluted soils using genetically engineered plants. J Soil Contam 1998; 7:497-509.

[8] Rugh CL, Senecoff JF, Meagher RB, Merkle SA. Development of transgenic yellow poplar for mercury phytoremediation. Nat Biotechnol 1998; 16:925-8.

[9] Rugh CL. Mercury detoxification with transgenic plants and other biotechnological breakthroughs for phytoremediation. In Vitro Cell Dev Biol - Plant 2001; 3: 321-5.
[10] Czakó M, Jang JC, Herr JM, Má rton L. Differential Manifestation of Seed Mortality Induced by Seed- Specific Expression of the Gene for Diphtheria-Toxin a Chain in Arabidopsis and Tobacco. Mol Gen Genet 1992; 235: 33-40.

[11] Czak M, Mrton L. The Herpes-Simplex Virus Thymidine Kinase Gene as a Conditional Negative-Selection Marker Gene in Arabidopsis-Thaliana. Plant Physiol 1994; 104: 1067-71.

[12] Sambrook J, Fritsch EF, Maniatis T. Molecular cloning: a laboratory manual. 2nd ed. 1989, Plainview, NY: Cold Spring Harbor Laboratory Press.

[13] Czakó M, Marathe RP, Xiang C, Guerra DJ, Bishop GJ, Jones JDG, Má rton L. Variable expression of the herpes simplex virus thymidine kinase gene in Nicotiana tabacum affects negative selection. Theor Appl Genet 1995; 91:1242-7.

[14] Kozuchowski J and Johnson DL. Gaseous emissions of mercury from an aquatic vascular plant. Nature 1978; 274:468-9.

[15] Bizily SP, Rugh CL, Summers AO, Meagher RB. Phytoremediation of methylmercury pollution: merB expression in Arabidopsis thaliana confers resistance to organomercurials. Proc Natl Acad Sci USA 1999; 96: 6808-13.

[16] Bizily SP, Rugh CL, Meagher RB. Phytodetoxification of hazardous organomercurials by genetically engineered plants. Nat Biotechnol 2000; 18:213-7.

[17] Gleba D, Borisjuk NV, Borisjuk LG, Kneer R, Poulev A, Sarzhinskaya M, Dushenkov S, Logendra S, Gleba YY, Raskin I. Use of plant roots for phytoremediation and molecular farming. Proc Natl Acad Sci USA 1999; 96: 5973-7. 